\title{
Europe's Hunger Games: Income Distribution, Cost Competitiveness and Crisis
}

\author{
Servaas Storm and C.W.M. Naastepad ${ }^{\star}$
}

The dominant view, both on the mainstream right and on the left, holds that the Eurozone crisis is a crisis of labour-cost competitiveness-with trade imbalances (and hence foreign indebtedness) being driven by divergences in relative unit labour costs (RULCs) between surplus and deficit countries. To re-balance Eurozone growth, the mainstream solution is a deflationary policy of 'internal devaluation' (i.e. cutting the wage share by as much as $30 \%$ ) in the deficit countries. The 'progressive' view holds that the surplus countries should adjust by raising their wage shares. We argue that both sides of this debate are wrong and unhelpful. Europe's trade imbalances are determined by domestic and world demand-whilst RULC divergences play only a negligible role. Eurozone growth can only be revived when Eurozone demand growth is restored, not by lowering wages here and/or raising them there. The current deflationary adjustment forced on the wage-led economies of Greece, Italy, Portugal and Spain is self-destructive: it is a 'confidence killer', not only deepening the free fall of southern European incomes but also damaging their productive base and productivity growth. The outlook is depressing-further increases in already high unemployment rates, inequality measures and poverty rates inconceivable in prosperous Europe just a few years ago - and arguably dystopian.

Key words: Macro-economic policy, Eurozone crisis, Income distribution, Price and non-price competitiveness

FEL classifications: E00, E02, E12, F02, F15

\section{A spectacle of sorts}

Dystopias are trending in contemporary popular culture. Novels and movies abound that deal with fictional societies within which humans, individually and collectively, have to cope with repressive, technologically powerful states that do not usually care for the well-being or safety of their citizens, but instead focus on their control and extortion. The latest resounding dystopian success is The Hunger Games-a box-office hit located in a nation known as Panem, which consists of 12 poor districts, starved for resources, under the absolute control of a wealthy centre called the Capitol. In the

Manuscript received 15 July 2013; final version received 28 February 2014.

${ }^{\star}$ Delft University of Technology. An earlier version of this article was presented at the 2013 Paris conference of the European Association of Evolutionary Political Economy. The authors are grateful to Dany Lang, Amitava Dutt, Thomas Ferguson and Engelbert Stockhammer for useful comments. Two anonymous referees provided very helpful comments. The authors are grateful to the Political Economy of Distribution Working Group of the Institute of New Economic Thinking for financial support.

(C) The Author 2014. Published by Oxford University Press on behalf of the Cambridge Political Economy Society. All rights reserved. 


\section{Page 2 of 28 S. Storm and C. Naastepad}

story, competitive struggle is carried to its brutal extreme, as poor young adults in a reality TV show must fight to death in an outdoor arena controlled by an authoritarian Gamemaker, until only one individual remains. The poverty and starvation, combined with terror, create an atmosphere of fear and helplessness that pre-empts any resistance based on hope for a better world.

We fear that part of the popularity of this science fiction action-drama, in Europe at least, lies in the fact that it has a real-life analogue: the Spectacle-in Debord's (1967) meaning of the term - of the current 'competitiveness game' in which the Eurozone economies are fighting for their survival. Its Gamemaker is the European Central Bank (ECB), which - completely stuck to Berlin's hard line that fiscal profligacy in combination with rigid, over-regulated labour markets has created a deep crisis of labour cost competitiveness-has been keeping the pressure on Eurozone countries so as to let them pay for their alleged fiscal sins. The ECB insists that there will be 'no gain without pain' and that the more one is prepared to suffer, the more one is expected to prosper later on. The contestants in the game are the Eurozone members-each one trying to bootstrap its economy out of the throes of the most severe crisis in living memory. The audience judging each country's performance is not made up of reality TV watchers but of financial (bond) markets and credit rating agencies, whose supposedly rational views can make or break any economy. The name of the game is boosting cost-competitiveness and exports - and its rules are carved into stone in March 2011 in a Euro Plus 'Competitiveness Pact' (Gros, 2011). Raising competitiveness here means reducing costs, and more specifically cutting labour costs, which means lowering the wage share by means of reducing employment protection, lowering minimum wages, raising retirement ages, lowering pensions and, last but not least, cutting real wages. Economic inequality, poverty and social exclusion will all initially increase, but don't worry: structural reforms hurt in the beginning, but their negative effects will be offset over time by changes in 'confidence,' boosting spending and exports. But it will not work, and the damage done by austerity and structural reforms is enormous; sadly, most of it was and is avoidable. The wrong policies follow from 'design faults' built into the Euro project right from the start - the creation of an 'independent' European Central Bank being the biggest 'fault', as it precluded the necessary co-ordination of fiscal and monetary policy and disabled the central banking system from providing support to national governments (Arestis and Sawyer, 2011). But as Palma (2009) reminds us, it is wrong to think about these 'faults' as being caused by perpetual incompetence - the monetarist Euro project should instead be read as a purposeful 'technology of power' to transform capitalism into a rentiers' paradise. This way, one can understand why policy makers persist in abandoning the unemployed.

\section{Contours of Europe's Hunger Game}

The first thing to note from Table 1, which details key dimensions of Europe's recent crisis, is that the Southern European (SE) countries-Greece, Italy, Portugal and Spain - are in free fall. During 2008-2013Q1, real GDP declined by more than 23\% in Greece and by around $7 \%$ in the other countries; the average income decline in the Euro area over the same period was just $2 \%$. The SE contraction is historically unprecedented. As shown by Figure 1, Greece's real GDP is still declining after 22 quarters (starting 2008Q4), whilst US GDP fell for 15 quarters during the Great Depression. Italy, Portugal and Spain are suffering a more prolonged recession than the UK during 1930Q1-1934Q1. There is no turn-around in sight. Inevitably, unemployment rates 
Table 1. Contours of Europe's hunger game (2008-2012/13)

\begin{tabular}{|c|c|c|c|c|c|}
\hline & Greece & Italy & Portugal & Spain & Euro-Area \\
\hline $\begin{array}{l}\text { Change in real GDP 2008-13 } \\
(\%)\end{array}$ & -23.3 & -7.1 & -7.9 & -6.4 & -2.0 \\
\hline $\begin{array}{l}\text { Change in manufacturing } \\
\text { output } 2008-12(\%)\end{array}$ & -26.1 & -7.8 & -11.8 & -22.1 & -8.3 \\
\hline $\begin{array}{l}\text { Change in real household } \\
\text { consumption } 2008-13(\%)\end{array}$ & -27.9 & -6.1 & -12.2 & -9.0 & -2.0 \\
\hline $\begin{array}{l}\text { Change in real domestic } \\
\text { demand } 2008-13(\%)\end{array}$ & -31.5 & -10.8 & -17.1 & -15.7 & -5.2 \\
\hline $\begin{array}{l}\text { Change in real investment } \\
2008-13(\%)\end{array}$ & -30.7 & -8.5 & -12.3 & -14.0 & -4.3 \\
\hline $\begin{array}{l}\text { Change in the (real) wage } \\
\text { share } 2008-12(\%)\end{array}$ & -5.9 & 1.6 & -4.6 & -6.9 & 1.8 \\
\hline $\begin{array}{l}\text { Change in the real wage rate } \\
\text { (per hour of work) } 2008- \\
12(\%)\end{array}$ & -14.2 & 0.9 & 0.2 & 2.0 & 4.5 \\
\hline $\begin{array}{l}\text { Change in hourly labour } \\
\text { productivity } 2008-12(\%)\end{array}$ & -8.3 & -0.7 & 4.8 & 8.9 & 2.7 \\
\hline $\begin{array}{l}\text { Unemployment rate in } 2013 \text {, } \\
\text { quarter } 1(\%)\end{array}$ & 26.6 & 11.9 & 17.6 & 26.5 & 12.1 \\
\hline $\begin{array}{l}\text { Unemployed persons } \\
\text { (millions) in } 2012\end{array}$ & 1.20 & 2.74 & 0.86 & 5.77 & 18.07 \\
\hline $\begin{array}{l}\text { Change in the unemployment } \\
\text { rate } 2008- \\
13 \mathrm{Q} 1 \%)\end{array}$ & 18.9 & 5.1 & 9.1 & 15.1 & 4.5 \\
\hline $\begin{array}{l}\text { Change in unemployment } \\
2008-12 \text { (million persons) }\end{array}$ & 0.83 & 1.05 & 0.39 & 3.18 & 6.13 \\
\hline $\begin{array}{l}\text { Youth unemployment rate in } \\
2013 \text { Q1 }(\%)\end{array}$ & 60.1 & 39.2 & 40.6 & 55.7 & 24.1 \\
\hline Income poverty in $2008(\%)$ & 18.5 & 18.3 & 17.0 & 15.9 & 14.6 \\
\hline $\begin{array}{l}\text { Poverty threshold in } 2011 \\
\quad \text { (euros per month) }\end{array}$ & 549 & 799 & 421 & 626 & \\
\hline $\begin{array}{l}\text { Increase in income poverty } \\
\text { during } 2008-11(\%)\end{array}$ & 4.4 & 2.4 & -1.2 & 5.1 & 1.8 \\
\hline $\begin{array}{l}\text { Increase in income poverty } \\
\text { during 2008-11 (1000 } \\
\text { persons) }\end{array}$ & 483 & 1,454 & -128 & 2,336 & 5,886 \\
\hline $\begin{array}{l}\text { Change in disposable income } \\
\text { during 2007- } \\
\text { 2010: all deciles (\%) }\end{array}$ & -4 & -1 & -1 & -3 & $-0.4^{\star}$ \\
\hline $\begin{array}{l}\text { Change in disposable income } \\
\text { during } 2007- \\
\text { 2010: bottom } 10 \%(\%)\end{array}$ & -8 & -6 & +2 & -14 & $-1.9^{\star}$ \\
\hline $\begin{array}{l}\text { Change in disposable income } \\
\text { during } 2007- \\
\text { 2010: top } 10 \%(\%)\end{array}$ & -4 & -1 & -1 & -1 & $-0.8^{\star}$ \\
\hline $\begin{array}{l}\text { Ratio of top } 10 \% \text { to bottom } \\
10 \% \text { in } 2008\end{array}$ & 10.6 & 8.8 & 10.0 & 10.0 & 8.0 \\
\hline $\begin{array}{l}\text { Increase in ratio top } 10 \% \\
\text { to bottom } 10 \% \text { during } \\
2008-11\end{array}$ & +0.3 & +1.7 & -0.6 & +4.9 & +0.2 \\
\hline
\end{tabular}


Table 1. Continued

Greece Italy Portugal Spain Euro-Area

Memo items

Fiscal deficit (\% of GDP) in $\quad-6.5 /-10.0-1.6 /-3.0-3.1 /-6.4+1.9 / \quad-0.7 /-3.7$ $2007 / 2012$

Public consolidated debt $\quad 107.4$ / $156.9103 .3 / 127.068 .4$ / 123.636 .3 / 84.266 .4 / 90.6 (\% of GDP) in $2007 / 2012$

Notes: At-risk-of-poverty rate is anchored at a fixed moment in time (2005). Income poverty is defined as the share of people living in households with less than $60 \%$ of median household income after social transfers. ${ }^{\star}$ indicates that the data are for OECD.

Sources: All data are from the Eurostat Database. Data on changes in disposable income are from OECD (2013).

The Great Depression (1929-1936) vs. the Eurozone Crisis (2008-....)
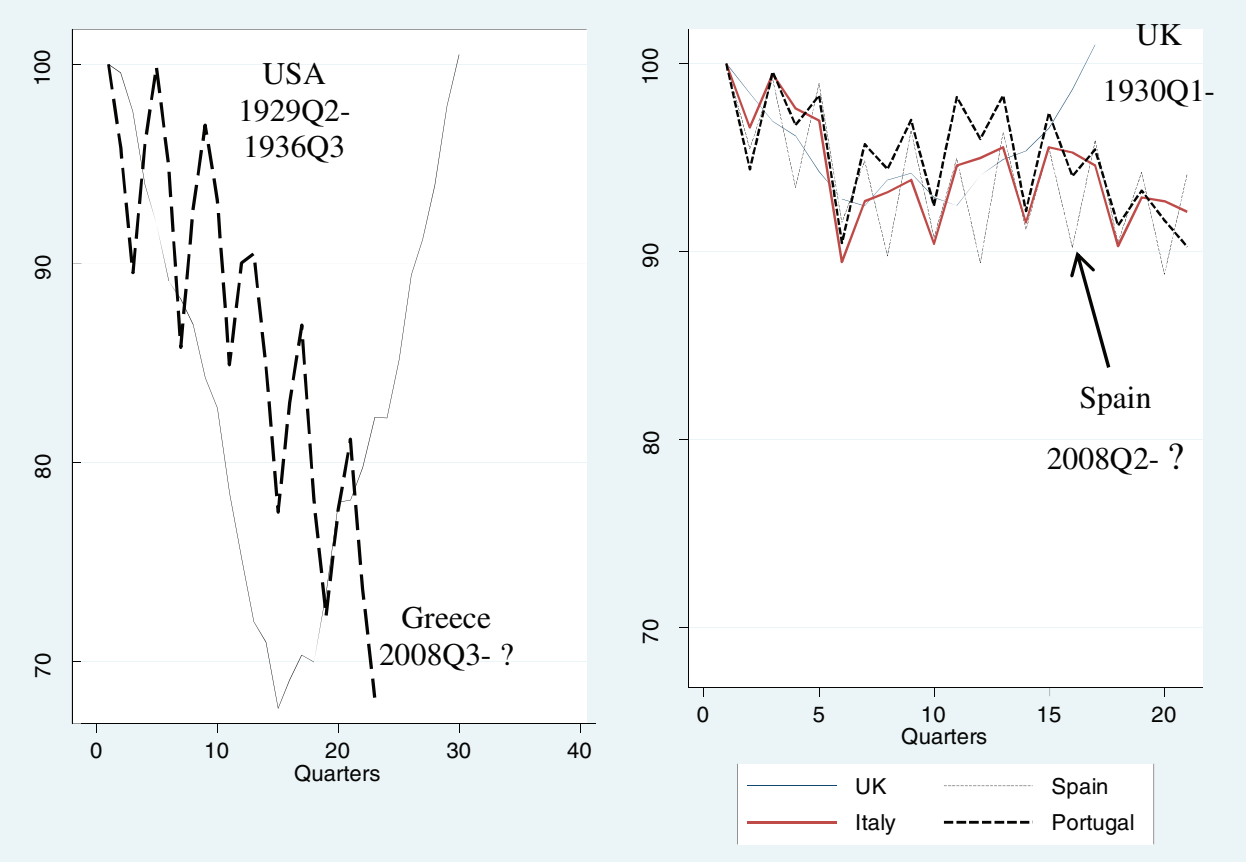

Figure 1. The Great Depression (1929-36) vs. the Eurozone crisis (2008-)

Notes: The curves represent real quarterly GDP in the post-crisis years. For the USA, the index of real GDP for 1929Q2 $=100$, and for the UK 1930Q1 $=100$. For Italy, Portugal and Spain, the index of real GDP for 2008Q2 $=100$. The Great Depression led to a cumulative income loss of $32.4 \%$ suffered over 15 quarters. It took US GDP another 15 quarters to recover from the crisis (real GDP was back at the level of 1929Q2 only in 1936Q3). Greek GDP peaked in 2008Q3 (= 100) and has been declining for 18 quarters; the cumulative loss until $2013 \mathrm{Q} 1$ is $31.8 \%$. Real GDP of Italy, Portugal and Spain continues to trend down after 17 quarters of crisis.

Sources: For the USA: Gordon and Krenn (2010); for the UK: Mitchell et al. (2009). Data for Greece, Italy, Portugal and Spain are from the Eurostat Database.

have shot up. Greece, Italy, Portugal and Spain now (2013) count an unprecedented 10.6 million unemployed workers-almost 6 million more than during 2007-8. More than one in four workers is unemployed in Greece and Spain, one in six in Portugal and one in nine in Italy. Youth unemployment is up, reaching 60\% in Greece and 55\% 
in Spain-whilst in Italy and Portugal 4 in every 10 young workers faces joblessness. Income poverty rates have increased during $2008-11$ by $4.4,2.4$ and 5.1 percentage points in Greece, Italy and Spain, whilst inequality has been rising sharply. The crisis is creating a more polarised society in which the poorest must fight for access to basic items such as critical medicines. Newspapers report on the lengthening queues for soup kitchens and the mounting numbers of homeless people in Greece and Spainunfolding scenes of almost wartime-like misery no one could think to exist in prosperous Europe just a few years ago.

The southern Eurozone is fast turning into a depressing world of closing of possibilities, hopes and dreams, a dark world of heightened inequalities, high unemployment, pay cuts, rising in-work poverty and people hunting for food through garbage cans because there is no welfare state to fall back on. The predictable outcome is political instability, street protests over austerity plans, rising xenophobia, and widespread existential anxiety, not unlike life in fictitious Panem. Europe's 'competitiveness game' has been cruel. We must understand what is wrong with it.

\section{Mainstream crisis narrative}

Europe's sovereign debt crisis started when EU governments were forced to bail out their collapsing ('too big to fail') commercial banks, all heavily implicated in and/or hurt by the crash of the US financial system of 2007-8. Even though the exterior 'crisis impulse' was (more or less) similar for all Eurozone members, the eventual crisis impacts have been asymmetric-Europe's periphery was hit much harder than its core. The dominant narrative explaining this diversity in the fall-out of the crisis is distinctly social Darwinist, holding up Germany as a role model for a 'competitive, flexible, fit' economic system, whilst Europe's southern periphery is seen as weak, uncompetitive-basically 'unfit' to cope with crisis due to 'decades of economic mismanagement'. As per Darwin, the 'unfit' economies must adapt - mutate or reform to become more competitive - or perish. This narrative dominates European policy discourses of and Europe's policy responses to the crisis. It is more conventionally framed in terms of NAIRU (non-accelerating inflation rate of unemployment) economics (Storm and Naastepad, 2012). The NAIRU explanation of the Eurozone crisis goes as follows (e.g. Dadush, 2010). The single European monetary policy turned out to be too loose for the SE countries for two reasons. One, in the early 2000s, as average Eurozone inflation was down due to frozen wages in high unemployment and slow-growing Germany and France, the ECB could and did lower its interest rates. Second, the adoption of the single currency helped lower (bond) interest rates of and create a surge in (financial market) confidence in Greece, Italy, Portugal and Spain, as it was expected that their institutions and incomes would converge to those of Europe's core countries. The low interest rates drove up domestic demand (mostly for construction and real estate), imports and growth in the periphery (Lane and Pels, 2012; Lane, 2013), but also raised indebtedness (as credit was cheap and in abundant supply from northern banks). The (construction) boom in the SE economies induced rapid real wage growth that outpaced productivity growth - a trend argued to be reinforced by their 'rigid' labour markets - and hence resulted in a loss of international cost competitiveness, which led to rising current account deficits and huge external debts. The post-euro growth model of southern Europe was brought to an abrupt end by the financial crisis, but arguably was not caused by it. Hence, peripheral Europe's crisis is not just a financial crisis but a far deeper crisis of fiscal profligacy and lack of cost competitiveness 


\section{Page 6 of 28 S. Storm and C. Naastepad}

caused by rigid labour markets. What is needed in the periphery, according to this diagnosis, is re-establishing cost competitiveness (clawing back a unit labour cost disadvantage of $10 \%$ or more), fiscal consolidation (engineering a fiscal adjustment of $5-10 \%$ of GDP) and a more balanced growth model.

Austerity, in this view, is a clear case of 'there is no alternative' (TINA). For one thing, it is widely felt that significant belt-tightening is only 'normal' after years of fiscal excess and rising public debts. For another, financial markets will punish cashstrapped countries not doing enough to slash their deficits by making it even more expensive for them to borrow. Austerity has meant radical reductions by up to $10 \%$ in (minimum and public sector) wages and pensions and sharp 'solidarity' increases in indirect and direct taxation (European Commission, 2012B). Unsurprisingly, synchronised austerity programmes throughout the EU have drastically reduced household disposable incomes-by $11.6 \%$ in Greece, $1.6 \%$ in Italy, $6.3 \%$ in Portugal and $4.3 \%$ in Spain only in 2012 (European Commission, 2012A) - and this in turn deepened the recession and raised fiscal deficits, as was recognised by the IMF (2012) (see Guajardo et al., 2011). However, neither this large-scale failure nor the intellectual collapse of the 'expansionary austerity' argument (Blyth, 2013) nor the Reinhart-Rogoff debacle (Herndon et al., 2013) have weakened the belief of policy makers that 'austerity is good' and 'public debt is bad' even in times of recession. Fiscal stimulus remains anathema-witness the recent reform of Europe's Stability and Growth Pact, which aims to prevent any fiscal faux pas by Eurozone states in future, in fact enshrining fiscal austerity in national law-bypassing national parliaments. Austerity thus defines the 'arena' within which Europe's competitiveness game is held.

\section{Cost-competitiveness redux}

With little hope left that austerity will ever become expansionary, the one option left to revive Eurozone growth is to expand exports. Hence, true to long-standing IMF dogma, the fund's managing director, Christine Lagarde, stresses the need for neoliberal structural reforms of Europe's 'sclerotic' labour markets to 'boost export competitiveness' and growth. The IMF has been using its leverage to push through 'modernising' reforms, by an intensification of Europe's 2020 strategy, to improve the supply-side performance of the crisis economies. The reforms include (further) labour market deregulation, opening up goods and services markets to greater competition, increasing spending on education, $\mathrm{R} \& \mathrm{D}$ and innovation at the expense of social expenditures and so on. However, these reforms will take years to affect growth, if they lead to meaningful improvement at all. The only quick fix to boost exports is by improving cost competitiveness and, in the single-currency area, this means cutting (real) wages and crushing the wage share a.k.a. relative unit labour costs (RULCs). If reducing RULCs provides an export-led way out of the recession, then it must also be true that the Eurozone crisis was caused by the deteriorating competitiveness of Europe's southern periphery vis-à-vis the north (Dadush and Stancil, 2011; Chen et al., 2012). Germany's cost competitiveness, in this view, explains why it has been able to successfully weather the crisis, whilst the periphery's lack of cost competitiveness is believed to explain its failure to do so. As shown in Figure 2, Germany managed to substantially lower its RULC during 1996-2011, whereas in most other countries relative labour costs rose since the introduction of the single currency. Hence, the image is that of a super-competitive Germany, which has boosted its cost competitiveness by keeping wages flat. In contrast, persistent increases in RULC in the periphery, caused 
by wage growth in excess of productivity growth, made SE (net) exports structurally uncompetitive. As a result, the SE countries started to run persistent current account deficits - and because these deficits tend to come with increasing external liabilities, they led to the SE sovereign debt crisis. It logically follows that the periphery needs internal devaluation - cutting wage cost (because Eurozone members cannot devalue their currency). However, estimates suggest that to rebalance, the SE economies need to cut wage costs by as much as $30 \%$ (Sinn, 2012; Stockhammer and Sotiropulos, 2012). This is hugely controversial, especially in a context where several EU countries competing for the same export markets decide to do so at the same time.

What is remarkable is that the mainstream narrative is shared by many progressive economists who buy into the same RULC logic. But whereas mainstream commentators consider Germany the only EMU country that got it all right, the progressive view holds that 'mercantilistic' German wage and trade policies are actually part of, if not the, problem. 'Germany has gained [cost] competitiveness within the Eurozone for the sole reason that it has been able to squeeze its workers harder [than the rest of the Eurozone]. Inevitably it has generated persistent current account surpluses against the [Eurozone] periphery', write Lapavitsas et al. (2011, p. 2) in a fairly typical statement. Germany's growing trade surpluses with southern Europe are proof of Germany's success in 'beggaring' its Mediterranean neighbours. 'With German unit labour costs undercutting those in other countries by an increasing margin, its exports flourished and its imports slowed down. Countries in southern Europe [. . . ] registered widening trade and current-account deficits', write Flassbeck and Lapavitsas (2013). In line with this, progressive economists argue in favour of higher real wages and higher inflation in Germany. The IMF changed sides in this debate, first arguing in favour of wage cuts in the periphery, but now advocating higher wages and a somewhat higher inflation rate in Germany. However, such calls for higher wages in Germany have been quickly sidelined. Simulations with the National Institute Global Econometric Model performed by the Dutch Central Bank (DNB, 2012), for instance, suggest that the cumulative

Relative Unit Labour Cost: Euro Area (1996-2011) $(\mathbf{2 0 0 0}=\mathbf{1 0 0})$

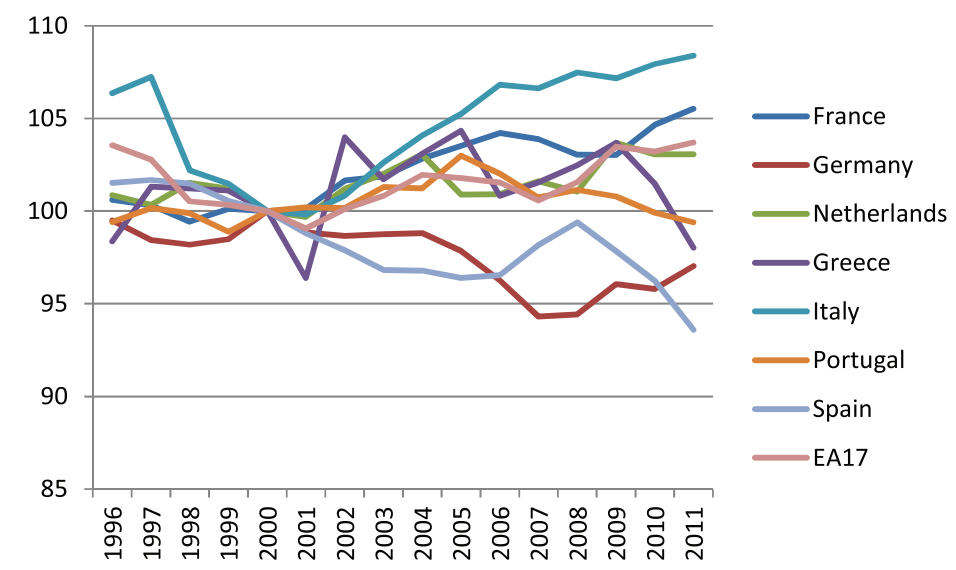

Figure 2. Relative unit labour cost: Euro area (1996-2011) $(2000=100)$

Note: RULC is real unit labour costs (total economy) relative to the rest of 35 industrial countries (double export weights).

Source: AMECO database. 


\section{Page 8 of 28 S. Storm and C. Naastepad}

impact of a 1 percentage point wage increase in Germany and the Netherlands on the SE economies is negligibly small (estimated over a period of four years), because most of the additional German and Dutch import demand is for countries other than the $\mathrm{SE}$ ones. Findings such as these further strengthen the demand for wage declines in the periphery.

\section{What is competitiveness?}

Perhaps surprisingly, economics lacks an agreed definition and measure of 'competitiveness'. Some (Arghyrou and Chortareas, 2008) define 'competitiveness' in terms of trade or current account surpluses, but it is generally accepted that these are not useful indicators in the Eurozone context (Wyplosz, 2010; Gros, 2011; Gaulier and Vicard, 2012). The reason is that European monetary integration led to an inflow of capital to the SE countries, as membership of the Euro area relaxed borrowing constraints for banks, firms and residents in the periphery (Blanchard and Giavazzi, 2002; Chen et al., 2011; Lane and Pels, 2012; Gabrisch and Staehr, 2013; Lane, 2013). This inflow of capital boosted domestic demand, which pushed up non-tradeables' prices as well as imports. Exports were largely unaffected by the growth in domestic demand, because they respond primarily to foreign demand and international prices. Hence, the current account imbalances of Greece, Italy, Portugal and Spain reflect excessive import growth, driven by the growth of heavily debt-financed domestic demand. Conversely, Germany developed a trade surplus because domestic demand slackened (following the wage squeeze) relative to trading partners' demand (Schröder, 2011). Growing trade imbalances are, in other words, not caused by changes in relative cost competitiveness. Indeed, Gabrisch and Staehr (2013) conclude, based on a panel data analysis for 27 EU countries (1995-2011), that changes in RULC do not Granger-cause changes in the current account balance. Gaulier and Vicard (2012) reach a similar conclusion. Both studies show that rising unit labour costs in the SE countries were a consequence of the current account imbalances, resulting from the 'positive' demand shock triggered by an inflow of over-optimistic capital from the core.

We concur with the view that SE current account imbalances are driven by capital flows from Europe's core to the periphery - whilst changes in RULCs did not have a discernible impact. In the Appendix we present an empirical analysis of import and export demand and trade balance changes for the SE countries (1995-2008). Our findings, which we carefully compare with relevant findings from the literature, can be summarised as follows. First, SE import growth (which mostly concerns intermediates and capital goods) is completely determined by domestic demand growth, especially investment, and import growth is insensitive (in a statistical sense) to RULCs. Second, SE exports are very sensitive to world income and less so to RULCs. Third, RULC changes did not affect trade balances of Greece and Portugal in a statistically significant manner, whilst explaining a mere 0.7 percentage points of the Spanish trade balance decline and 7.9 percentage points of that of Italy. The bottom line is that RULCs are basically irrelevant. Slashing down the wage share makes no economic sense. The reason for this is not difficult to understand. What matters in international competition is the 'gross output price' of a product or service - the full (national accounts) price, which includes the costs of intermediate inputs and labour as well as a profit margin. Table 2 details the composition of the gross output price for the manufacturing sectors in the SE economies (around 2005). Unit labour costs (ULCs) make up only about $16 \%$ of the manufacturing gross output price, whereas intermediate input 
Table 2. Unit labour costs and gross output prices, southern Europe (mid-2000s)

\begin{tabular}{lllll}
\hline & Greece & Italy & Portugal & Spain \\
\hline Intermediate input costs per unit of output & 0.68 & 0.74 & 0.73 & 0.73 \\
Unit labour costs: ULC & 0.15 & 0.16 & 0.17 & 0.16 \\
Total unit variable cost: $v c=1+2$ & 0.83 & 0.90 & 0.90 & 0.89 \\
Mark-up rate: $\pi$ & 0.21 & 0.11 & 0.11 & 0.12 \\
Gross output price: $(1+\pi)^{\star} v c$ & 1.00 & 1.00 & 1.00 & 1.00 \\
Implied 'pass-through' elasticity & 0.18 & 0.18 & 0.19 & 0.18 \\
of a 1 percentage point decline in ULC & & & &
\end{tabular}

Notes: Gross output price is the average for the manufacturing sectors (C15T16 - C36T37). The gross output price $p$ is defined as: $p=(1+\tau)\left[W \lambda^{-1}+\alpha\right]$, where $\alpha$ is intermediate input cost (per unit of output), W is the nominal wage rate, $\lambda$ is labour productivity and $\tau$ is the mark-up rate. $W \lambda^{-1}=\mathrm{ULC}$. Net indirect taxes have been included in intermediate input costs. The implied 'pass-through' elasticity measures the decline in the gross output price (in percentage points) caused by a 1 percentage point decline in ULC. The estimates in the last row indicate that if manufacturing ULCs are reduced by $10 \%$, output prices fall by about $1.8 \%$.

Source: Calculated using the OECD STAN Database input-output tables.

costs account for $72 \%$ of total costs and the profit share is $12 \%$. If ULC increase by 1 percentage point, the gross output price increases by just $0.18 \%$ when we assume the complete 'pass-through' of higher labour costs onto prices. The implication is, to illustrate, that a relative-price elasticity of export demand of -1 is consistent with a RULC elasticity of export demand of just -0.18 . However, if cost pass-through is not complete, but, say, only half (which is realistic), a relative price elasticity of export demand of -1 is consistent with a RULC elasticity of export demand of just -0.09 . What is not understood by most is that RULC trade elasticities by definition take a value of only one-fifth to one-tenth of the respective price elasticities (in absolute terms).

This explains why the statistical evidence on the inverse relationship between export growth and the growth of RULCs is overwhelmingly weak (Storm and Naastepad, 2007, 2012; Felipe and Kumar, 2011). IMF economists Danninger and Joutz (2007, p. 15), in an econometric investigation of Germany's export success (1993Q1-2005Q4), find that improved cost competitiveness 'played a comparatively smaller role in explaining the brisk export growth' than trade relationships with fast growing countries, relative cost improvements accounting for less than $2 \%$ of German export growth. ECB economists Di Mauro and Forster (2010, p. 16) concur, concluding that 'since the late 1990s there have been signs of this correlation [between RULC and export growth] weakening'. World Bank economists Diaz Sanchez and Varoudakis (2013, p. 17) find, based on the estimation of a panel data analysis over 1975-2011 for 13 Eurozone countries, that 'for the periphery, the contribution of [RULC] changes to external imbalances appears negligible'. Gabrisch and Staehr's (2013, p.16) econometric results show that changes in RULCs 'do not affect changes in the current account balance in any statistically or economically significant manner'. Even European Commission (2010) recognises that Germany's massive export boom over 1999-2010 is almost completely due to the growth of its export markets, whereas the contribution of more competitive pricing on German export growth is barely noticeable. We are in good company when we conclude that RULCs do not matter much for competitiveness. ${ }^{1}$

\footnotetext{
${ }^{1}$ When dismissing RULCs as a factor determining competitiveness and current account imbalance, we are not implying that the same holds true for the (real) exchange rate. Unlike RULCs, the exchange rate is a 'macro price': any change in the exchange rate will change the total foreign currency price (and not just the labour cost component).
} 


\section{Page 10 of 28 S. Storm and C. Naastepad}

This does not mean that 'competitiveness' is unimportant, however. It is non-price competitiveness that matters - not price or cost competitiveness. This is brought out in studies by the ECB (2005, 2012), which dig deeper into the data and decompose Eurozone export performance into a 'structure' effect and a 'competitiveness' effect. If a country is specialised in commodities and destination markets where demand growth is above average in comparison to other products and markets, its share in world exports must increase if it manages to maintain constant market shares in these dynamic commodities and geographical destinations. This influence on a country's overall export market share of the commodity composition of its exports as well as its destination markets is called the 'structure effect'. Once the structure effect is determined, a country's export market share growth can be decomposed into the structure effect and a residual term, known as the 'competitiveness effect' (CE), which-by definition-captures the influence of price as well as non-price factors (including $\mathrm{R} \& \mathrm{D}$, regulation and institutions). Table 3 presents estimates of the structure and competitiveness effects for selected Eurozone economies in the period 1996-2007.

Let us first consider Germany. The export market share of Europe's export juggernaut has grown by 0.45 percentage points on average per year during 1996-2007. This was the result of (i) an advantageous export structure, geared towards rapidly growing regions including non-euro EU countries, other Eastern Europe, Russia and China (ECB, 2005; Danninger and Joutz, 2007; European Commission, 2009); and (ii) robustly growing medium-tech commodities (motor vehicles and agricultural and industrial machinery), for which world markets are growing at an above average rate. Germany is strong in medium-high-technology exports and it manages to sell these

Table 3. Sources of export market share growth (1996-2007): selected Eurozone members (average annual growth rates \%)

Country's Country's export market share growth explained by: export market share growth Price/non-price Structure effect (SE): competitiveness effect (CE) Destination Commodity Interaction Total market effect composition effect structure effect effect

\begin{tabular}{lrrrrrr}
\hline France & -2.99 & -4.08 & 0.13 & 0.45 & 0.50 & 1.08 \\
Germany & 0.45 & -1.01 & 0.89 & 0.29 & 0.28 & 1.46 \\
Netherlands & 1.95 & 1.57 & 0.63 & 0.01 & -0.26 & 0.38 \\
Greece & -0.37 & -2.24 & 2.00 & -0.45 & 0.28 & 2.05 \\
Italy & -1.19 & -1.74 & 0.68 & -0.25 & 0.13 & 0.55 \\
Spain & 1.28 & 0.59 & 0.11 & 0.10 & 0.48 & 0.70 \\
Portugal & -2.50 & -2.11 & -0.23 & -0.86 & 0.70 & -0.21 \\
Euro area & -0.34 & -2.45 & 1.14 & 0.31 & 0.65 & 2.10 \\
\hline
\end{tabular}

Notes: Export market share growth of country $i$ is defined as the difference between country $i$ 's export growth and global export growth. The 'structure effect' is the growth rate differential which is due to a country's specialization; the 'destination market effect' measures whether specialization is tilted towards higher-growth destination markets; the 'commodity composition' effect measures whether specialisation is directed towards higher-growth product markets; the interaction effect embodies the impact of particular product-market combinations and the 'competitiveness effect' is the residual.

Source: Cafiso (2009); see also ECB (2005). 
goods at above average prices. This is clear from Germany's strong presence in 'upmarket products', which fetch the highest prices and account for more than half of German exports. On account of the 'structure effect', Germany's export market share would have increased by $1.46 \%$ per year-but remarkably, Germany's actual export market share growth was just $0.45 \%$ per year. This implies that the CE for Germany was negative, reducing German export growth by about 1 percentage point below world export growth. 'Made in Germany' therefore lost competitive edge, notwithstanding the decline in its RULC.

Greece, Italy and Portugal lost market share. They specialise in low-tech exports for which world markets are growing at a below-average rate. Greece and Italy do cater to more dynamic destinations, whereas Portugal exports to slow-growing (saturated) markets. All three countries lost competitiveness $(\mathrm{CE}<0)$-causing their export market shares to decline roughly twice as fast as Germany's. Low-tech exporters Greece, Portugal and also Italy have lost global market share, because their exports overlap more with (low-cost) Chinese exports and therefore face more direct exposure to Chinese competition. ${ }^{2}$ Medium/high-tech sectors, on the other hand, have (until now at least) been exposed less to competition from China. Spain's export performance has been different. During 1996-2007, Spain gained export market share as a result of a positive (but small) structure effect and a (small) gain in overall competitiveness. However, Spain's export success, which coincides in time with a fall in its RULC (Figure 2), did not prevent a deterioration of its current account, because domestic demand-driven imports increased even more (see Appendix). The bottom line is that the exports of Germany and the SE countries are concentrated in technologically different commodities and different market destinations. Germany has a market share of $18 \%$ in the total world exports of the top 100 most complex products-against Italy $3.1 \%$, Spain $0.9 \%$, Greece $0.02 \%$ and Portugal 0.04\% (Abdon et al., 2010). There are few Mediterranean names that can rival BMW, Bosch, Mercedes, SAP or Siemens. Of the Greek and Portuguese exports, 33\% and 22\%, respectively, belong to the least complex product group. The Mediterranean export structure (in terms of complexity) is similar to that of China. This is where the real competitiveness problem of the SE countries lies: they are locked in to lower and middle levels of technology. Reducing the wage share is never going to solve that problem (Felipe and Kumar, 2011).

\section{The economic consequences of internal devaluation}

Even if there are appearing cracks in the austerity dogma, belief in the inescapable necessity of 'modernising reforms' and 'internal devaluation' has remained intactactually, it has become even stronger with the softening of the IMF's position on austerity. So what can we reasonably expect from such a reduction in real wages in the periphery in terms of higher (net) exports and additional economic growth? Clearly, the growth impact depends on how important exports and imports are as a share of GDP, on how sensitive exports and imports are to changes in RULCs, on how strong the multiplier impact on the domestic economy is of net export growth and finally on whether the resulting net export-led growth is offset by a decline in domestic demand in response to the wage cutting. Export shares in GDP are generally low (Table 4),

\footnotetext{
${ }^{2}$ Whilst the overlap in export specialisation with China is $52 \%$ for Portugal, $41 \%$ for Italy and $34 \%$ for Greece, it is only $31 \%$ for Germany and 22\% for France (Di Mauro et al., 2010).
} 


\section{Page 12 of 28 S. Storm and C. Naastepad}

Table 4. How much does southern Europe's GDP growth change due to an internal devaluation of $30 \%$ ?

\begin{tabular}{|c|c|c|c|c|}
\hline & Greece & Italy & Portugal & Spain \\
\hline Import-GDP ratio (1995-2008) & 0.32 & 0.23 & 0.36 & 0.27 \\
\hline Income elasticity of imports & 2.0 & 2.4 & 1.9 & 2.0 \\
\hline RULC elasticity of imports & -0.15 & -0.05 & -0.15 & -0.05 \\
\hline Export-GDP ratio (1995-2008) & 0.21 & 0.25 & 0.28 & 0.25 \\
\hline RULC elasticity of exports & 0.15 & 0.20 & 0.40 & 0.30 \\
\hline \multicolumn{5}{|l|}{$\begin{array}{l}\text { Impact on real GDP growth of a } 1 \text { percentage point } \\
\text { reduction in ULC growth: }\end{array}$} \\
\hline impact due to higher net export growth $C_{T}$ & +0.80 & +0.63 & +1.24 & +0.95 \\
\hline impact due to lower domestic demand growth $C_{D}$ & -1.41 & -0.77 & n.a. & -1.12 \\
\hline total impact $C=C_{D}-C_{T}$ (in percentage points) & -0.61 & -0.14 & n.a. & -0.16 \\
\hline $\begin{array}{l}\text { Impact of an increase in OECD income growth by } \\
1 \text { percentage point (see equation A.18) }\end{array}$ & 1.33 & 0.91 & 0.88 & 1.51 \\
\hline \multicolumn{5}{|l|}{ Cumulative impact on real GDP after 5 years of: } \\
\hline $\begin{array}{l}\text { a } 30 \text { percentage point decline in ULC (= the } \\
\text { wage share) }\end{array}$ & -19.6 & -4.7 & n.a. & -5.6 \\
\hline a 5 percentage point increase of OECD Income & 6.8 & 4.6 & 4.5 & 7.8 \\
\hline
\end{tabular}

Notes: The estimations are based on a modified version of the macro model of Storm and Naastepad (2012), as explained in the Appendix.

Data sources: The average import-GDP and export-GDP ratios are calculated for 1995-2008 using the AMECO Database. The long-run income elasticities of export and import demand and the RULC elasticities of import and export demand are from the Appendix.

varying between $21 \%$ for Greece and $28 \%$ for Portugal. Hence, a growth strategy based on boosting export growth through wage cuts runs the risk of being counterproductive, because it may destroy domestic demand, which is about three times the size of export demand. In Table 4 appear the RULC elasticities of imports and exports used in our model analysis. To repeat: a RULC elasticity of import demand of -0.15 corresponds to a relative-price elasticity of import demand of between -0.75 and -1.5 , which are values lying towards the higher end of ECB and IMF staff estimates for Europe.

We have quantified the effects of internal devaluation using a modified version of the macroeconomic growth model $^{3}$ of Storm and Naastepad (2012), outlined in the Appendix. The resulting impact estimates for the SE economies appear in Table 4 . We estimate the total impact on economic growth of a $1 \%$ and a (cumulative) $30 \%$ cut in real wage growth (and hence in ULC growth). We define $C_{D}$ (in equation A.15 in the Appendix) as the impact on domestic demand growth of a 1 percentage point reduction in real wage growth. $C_{D}$ likely takes a negative value-indicating that domestic demand drops off when real wages are cut. $C_{T}$ is the effect on net export growth of a 1 percentage point reduction in RULC growth (equation A.16). $C_{T}$ is positive for normal values of the price elasticities of imports and exports - indicating that an internal devaluation does indeed increase net exports. The total impact on output growth equals $C=C_{D}+C_{T}$. We treat each country in strict isolation from the others. However, if all economies simultaneously 'beggar their neighbours' by reducing wages by about

\footnotetext{
${ }^{3}$ Our model deals with what Setterfield (2002) has called a conditional or provisional (medium-run) equilibrium, not with long-run equilibrium in a classical or a NAIRU sense (see Storm and Naastepad, 2012, p. 56).
} 
the same extent, their RULCs do not change and hence their net exports remain unchanged. But if at the same time the wage cuts do reduce domestic demand, then imports fall (through the income effect) and as a result, other countries experience a fall in their exports. Hence, as Robinson (1946/47, p. 112) wrote, 'The more [a country] makes use of wage-cutting (or exchange depreciation) or of protection, the harder is employment to be maintained in the rest of the world'. That the fallacy of compositions holds when it comes to exporting one's economy out of recession has been shown by Capaldo and Izurieta (2013) and Onaran and Galanis (2012). Our estimates of $C$ will therefore over-state the growth-promoting impact of an internal devaluation-by approximately $0.2-0.4$ percentage points per cent of unit labour cost (ULC) reduction (Onaran and Galanis, 2012, Table 13).

With low trade shares in GDP and little sensitivity of imports and exports to RULCs, it should come as no surprise that the impact on GDP growth of more rapid net export growth due to cutting the real wage by 1 percentage point is modest. The higher net export growth raises real GDP growth by 0.63 percentage point per year in Italy, 0.8 percentage point in Greece, 0.95 percentage point in Spain and 1.24 percentage points in Portugal. But the internal devaluation is at the same time destroying domestic demand-especially consumption. This is no surprise, as a majority of studies for Europe $^{4}$ finds that domestic demand growth is wage-led. We use our own estimates (Storm and Naastepad, 2012) of the impact on domestic demand of a 1 percentage point reduction in ULC growth for Greece, Italy and Spain (we lack estimates for Portugal). The resulting growth impacts should be treated as being 'rough', but representative estimates. Wage-led domestic demand growth in Europe's periphery falls - in response to the 1 percentage point cut in real wage growth-by 0.77 percentage point in Italy, 1.12 percentage points in Spain and by 1.4 percentage points in Greece, nullifying the gains from trade. We further estimate the cumulative decline in real GDP of a policy to reduce ULC by $30 \%$ over a period of five years. The outcome is cruel: the overall impact of improving cost competitiveness is to actually sink the economy-further reducing real GDP by almost $20 \%$ in Greece and by about $5 \%$ in Italy and Spain. Internal devaluation in the periphery backfires, deepening an already painful recession. How all this is supposed to help win back 'confidence' is a mystery. It is simply impossible for the ECB to continue insisting that for SE there will be 'no gain without pain'.

We finally compare the internal devaluation scenario with an alternative scenario in which OECD countries manage to raise their combined real GDP growth rate by $1 \%$ per year by means of co-ordinated fiscal stimulus. Through the income effect, this would boost SE export growth and hence kick-start recovery. Over a period of five years, real GDP of Greece would grow by $6.8 \%$, that of Italy and Portugal by $4.5 \%$ and Spanish incomes by $7.8 \%$. Obviously, restoring Eurozone growth by fiscal stimulus is not a live option now.

\section{A dangerous obsession}

The real damage due to a strategy of internal devaluation is likely to be even bigger than our estimates in Table 4 already suggest. The reason is that even though there is much lofty talk about 'building a knowledge economy' and 'promoting smart growth

\footnotetext{
${ }^{4}$ Evidence on wage-led domestic demand in the EU is provided by Storm and Naastepad (2007, 2012); Hein and Vogel (2008); Stockhammer et al. (2009); Onaran and Galanis (2012).
} 


\section{Page 14 of 28 S. Storm and C. Naastepad}

and technology-based manufacturing' in Europe's periphery, what is not understood is that a policy of further labour market deregulation will actually slow down laboursaving technological progress, depress labour productivity growth and damage productive potential in the longer run (Storm and Naastepad, 2012). This claim stands in contrast to the mainstream view that competition drives innovation and technological progress. The 'modernising reforms', in this view, will create a more competitive system because they entail the removal of regulatory barriers in goods and labour markets to allow firms to adjust flexibly and against low cost to their rapidly changing global environments. The pinnacle of the reforms is the (further) deregulation of labour markets, as 'rigid' labour market rules and institutions make Mediterranean labour costly and hinder firms in their competitive struggles. The idea is to create more flexibility in the labour market for enterprises, curb union wage-bargaining power, reduce workers' sense of entitlement to job security and welfare and improve labour mobility. What is not understood is that, as Robert Solow (1998) once remarked, every one of these regulations was intended to promote a desirable social purpose-often as a 'secondbest' response to a 'market failure' (see Lee and McCann, 2011).

Moreover, in flexible labour markets, firms will invest less in workers' firm-specific human capital and this hurts productivity as well (Auer et al., 2005). Labour market deregulation may affect productivity through its impact on worker motivation and effort, as it erodes social capital and trust in the labour relation (Storm and Naastepad, 2009, 2012). Likewise, lower wages and more flexible labour slow down the process of Marx-biased technical change (Foley and Michl, 1999), enabling inefficient firms to stay in the market and discouraging structural change. Lower wage growth further means lower aggregate demand growth (as shown in Table 4), and this limits the deepening of the division of labour and slows down the process of learning by doing (Hein and Tarassow, 2010). Moreover, lower wage and demand growth reduce the pace at which older vintages of capital stock are being scrapped and new equipment, embodying the latest more productive technologies, is being installed. Taken together, lower wage growth gets reflected in lower labour productivity growth and weaker export performance (Buchele and Christiansen, 1999; Storm and Naastepad, 2009, 2012; Kleinknecht et al., 2013).

To interpret Germany's export success as being the result of its increased cost competitiveness (as Flassbeck and Lapavitsas, 2013, want us to believe) is not only too narrow a take but plain wrong. Space prevents us from going into much detail, so suffice it to say that Germany's success is the vindication of its stubbornness to remain a highly regulated and co-ordinated manufacturing economy, keeping true to its artisanal roots. The regulation takes the form of work councils with which firms have to share power. The artisanal roots lie in Germany's Mittelstand, the small- to medium-sized enterprises (often family-owned) with strong ties to local communities that specialise and innovate in high-quality niche products. As competition from cheap labour abroad has placed a premium on innovation, skill and high quality, Germany's Mittelstand has flourished. It is the stability of its links - with schools, local (co-operative) banks, businesses, apprentices and the wider community - that gives the Mittelstand companies their competitive edge. This system, with 'checks and balances' on firms' behaviour and markets, works because it creates commitment, both of employees (who think as they work) and of finance, which is fundamental to innovation, technical change and continuous improvement. As Wolfgang Streeck explains, the 'constraints [imposed on Germany's firms] eventually proved beneficial. Firms accepted the challenge and got 
ahead by improving and innovating, particularly in the global market, focusing on quality not price'. (quoted in Coman, 2013). Germany thus concentrated on building up manufacturing non-price competitiveness, which shows up in strong product design, high quality, innovation and technological sophistication and reliability.

This brings us to the real problem: the wide differentials in labour productivity and technological capabilities between members of the Eurozone (Table 5). Average hourly productivity levels of Greek, Portuguese and Spanish workers are far below Germany's productivity levels. Table 5 also presents evidence on the diverging manufacturing and export structures in terms of technological sophistication. Europe's Competitiveness Pact, which is weighing almost exclusively on cutting ULCs, in combination with the fundamentally neoliberal Europe 2020 strategy (Pianta and Lucchese, 2012), will lock the southern Eurozone even more strongly into low-wage, relatively non-dynamic export specialisation patterns and tourism (as employment option of last resort). Imbalances within the Eurozone can only be reduced if the peripheral countries succeed in catching up with German productivity and technological potential. Through its single-minded emphasis on wages and ULCs, the competitiveness game will be achieving the exact opposite. 'Perhaps', Keynes (1919, p. 238) wrote, 'it is historically true that no order of society ever perishes save by its own hand'. With GDP in free fall and unemployment up, people are increasingly frustrated and dangerous because they have no voice, and hence they are vulnerable to the siren calls of extreme political parties. Few today can conceive of a complete breakdown of liberal institutions and disintegration of democratic consensus. But let Judt (2010, p. 221) reminds us of 'the ease with which any society can descend into Hobbesian nightmares of unrestrained atrocity and violence'.

There is no need, however, to accept such an outcome as inevitable. A radically rethought industrial policy, in place of the broken Europe 2020 Strategy and in combination with much stricter regulation of financial markets, could help the SE countries catch up with the core. However, to be effective, industrial policy should satisfy two conditions. First, it must be hands-on, with governments picking winners and public support helping pull innovation and stimulate investments (Mazzucato, 2013), for example, in renewable energy systems, public transport and education and health (for ideas on the governance and funding of this, see Pianta and Lucchese, 2012). Second, it should be based on the understanding that it is not price-based market competition that is driving innovation, but rather-as stressed by Keynes-social co-ordination of economic decision making, which imparts (conditional) order and stability to our fundamentally unstable capitalist system. Regulation and co-ordination do pay off in terms of higher productivity growth (Storm and Naastepad, 2012).

\section{Power and the useful economist}

We will not end our article by pointing out what needs to be done to save the Eurozone from self-destructing. There is no shortage, after all, of rescue plans, and many of them make good sense, including the proposals, modest and less modest, by Varoufakis et al. (2013), Soros (2013), Les Economistes Atterrés (http://www.atterres.org/\#translatefr) and the Euro Memorandum Group (http://www.euromemo.eu/show/6535543. html). Obviously, none of these proposals are being seriously entertained by the powers that be, as long as these stick to the mainstream view that austerity is TINA and the SE needs to re-balance by drastic internal devaluations and deregulation. More 


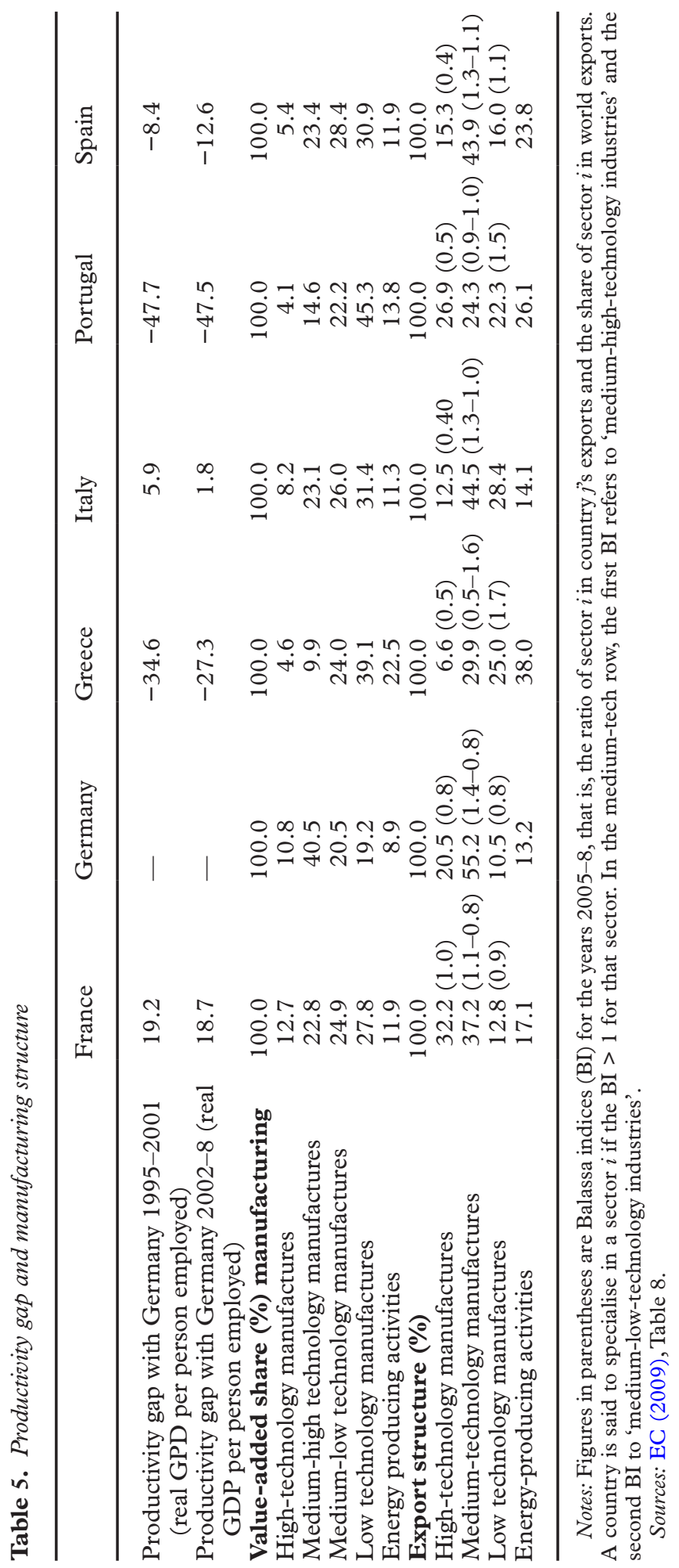


important, nothing will happen as long as the public remains acquiescent-accepting the mainstream's claim that its economics has no content of power and politics but is 'neutral'-even though in actual fact, it is defending the status quo and often (even worse) advocating change that favours the interests of large capital. 'Such an economics', as Galbraith (1972, p. 11) pointed out long ago, 'is not neutral. It is the influential and invaluable ally of those whose exercise of power depends on an acquiescent public'. It is precisely this role-helping depoliticise its policy prescriptions and nullify the suspicion that economics is not neutral-which makes the economist useful.

This is why Europe's competitiveness game is a spectacle indeed. Helped by useful economists, it dis-empowers and dis-enfranchises the electorate by de-politicising the rules of the game. These are left instead to financial markets to determine, whilst the public is reduced to passive powerless 'watchers', not co-creating participants. The real game, therefore, is not about competitiveness: it is a battle over ideas, the 'ideas of economists and political philosophers' which 'are more powerful than is commonly understood. Indeed, the world is ruled by little else', as Keynes (1936/1973) observed. Keynes's teacher, Cambridge economist Alfred Marshall (who was no raving radical), used to keep a photograph of a worker on his desk to remind himself of the rationale for his work and for whom it should be directed. ${ }^{5}$ This may seem excessively idealistic today, but we must remember, however, as Ghosh (2013) points out, that economics emerged from moral philosophy, which wanted not only to understand the world but also to change and improve it. For Marshall and Keynes this was still clear. But not so anymore: the profession has lost its purpose as well as its dignity somewhere along the way and has become 'a subject which features defeated expectations' (Galbraith, 1972, p. 1). Europe's struggle to get out of the deepest crisis in living memory is the right occasion to restore the profession's sense of purpose.

\section{Bibliography}

Abdon, A., Bacate, M., Felipe, J. and Kumar, U. 2010. 'Product Complexity and Economic Development', Levy Economics Institute of Bard College Working Paper No. 616,

Andersen, P. S. 1993. The $45^{\circ}$-rule revisited, Applied Economics, vol. 25, 1279-84

Arestis, P. and Sawyer, M. 2011. The design faults of the Economic and Monetary Union, Fournal of Contemporary European Studies, vol. 19, no. 1, 21-32

Arghyrou, M. G. and Chortareas, G. 2008. Current account imbalances and real exchange rates in the Euro area, Review of International Economics, vol. 16, no. 4, 747-64

Athanasoglou, P. P. 2011. 'The Role of Product Variety and Quality and of Domestic Supply in Foreign Trade', Bank of Greece Working Paper 128

Athanasoglou, P. P. and Bardaka, I. C. 2010. New trade theory, non-price competitiveness and export performance, Economic Modelling, vol. 27, no. 2, 217-28

Auer, P., Berg, J. and Coulibaly, I. 2005. Is a stable workforce good for productivity?, International Labour Review, vol. 144, no. 3, 319-43

Bagnai, A. 2010. Structural changes, cointegration and the empirics of Thirlwall's law, Applied Economics, vol. 42, no. 10, 1315-29

Bayoumi, T., Harmsen, R. and Turunen, J. 2011. 'Euro Area Export Performance and Competitiveness', IMF Working Paper WP/11/140

Bennett, H., et al. 2008. 'Competitiveness in the Southern Euro Area: France, Greece, Italy, Portugal, and Spain', IMF Working Paper WP/08/112

Blanchard, O. and Giavazzi, F. 2002. Current account deficits in the Euro area: the end of the Feldstein-Horioka puzzle?, Brookings Papers on Economic Activity, vol. 2002, no. 2, 147-86

Blyth, M. 2013. Austerity: The History of a Dangerous Idea, Oxford, Oxford University Press

5 The anecdote is due to Ghosh (2013). 


\section{Page 18 of 28 S. Storm and C. Naastepad}

Buchele, R. and Christiansen, J. 1999. Labor relations and productivity growth in advanced capitalist economies, Review of Radical Political Economics, vol. 31, no. 1, 87-110

Bussière, M., Callegari, G., Ghironi, F., Sestieri, G. and Yamano, N. 2011. Estimating trade elasticities: demand composition and the trade collapse of 2008-09, Mimeo

Cafiso, G. 2009. 'The Export Performance of the Euro Area Countries in the Period 19962007', MRPA Paper, available at http://mpra.ub.uni-muenchen.de/20263/

Capaldo, J. and Izurieta, A. 2013. The imprudence of labour market flexibilization in a fiscally austere world, International Labour Review, vol. 152, no. 1, 1-26

Chen, R., Milesi-Ferretti, G. M. and Tressel, T. 2012. 'External Imbalances in the Euro Area', IMF Working Paper WP/12/236

Coman, J. 2013. How did Germany become the new champion of Europe?, Observer, 1 June; http://www.guardian.co.uk/world/2013/jun/01/germany-champion-europe

Dadush, U. and contributors. 2010. Paradigm Lost: The Euro in Crisis, Washington, DC, Carnegie Endowment for International Peace

Dadush, U. and Stancil, B. 2011. Is the euro rescue succeeding?, VoxEu.org, 8 June

Danninger, S. and Joutz, F. 2007. 'What Explains Germany's Rebounding Export Market Share?', IMF Working Paper WP/07/24

Debord, G. 1967. La Société du Spectacle, Paris, Les Éditions Gallimard

Diaz Sanchez, J. L. and Varoudakis, A. 2013. 'Growth and Competitiveness as Factors of Eurozone External Imbalances', World Bank Policy Research Working Paper 6732

Di Mauro, F. and Forster, K. 2010. 'Globalisation and the Competitiveness of the Euro Area,' ECB Occasional Papers Series No. 97

Di Mauro, F., Forster, K. and Lima, A. 2010. 'The Global Downturn and its Impact on Euro Area Exports and Competitiveness', ECB Occasional Papers Series No. 119

DNB. 2012. Noord-Europese loonimpuls draagt niet bij aan herstel van handelsbalans periferielanden. DNBulletin, 15 August

ECB. 2005. 'Competitiveness and the export Performance of the Euro Area', ECB Occasional Paper Series No. 30

ECB. 2012. 'Competitiveness and External Imbalances within the Euro Area', ECB Occasional Paper Series No. 139

European Commission. 2009. 'The Evolution of EU and Its Member States' Competitiveness in International Trade', Final Report CEPII-CIREM ATLASS consortium

European Commission. 2010. Quarterly Report on the Euro Area. Special Issue: The Impact of the Global Crisis on Competitiveness and Current Account Divergences in the Euro Area, Brussels, European Commission, Directorate-General for Economic and Financial Affairs

European Commission. 2012A. 'The Distributional Effects of Fiscal Consolidation in Nine EU Countries', Research Note 01/2012, European Commission, Directorate-General for Employment, Social Affairs and Inclusion

European Commission. 2012B. Social Europe. EU Employment and Social Situation. Quarterly Review, Brussels, EC

Felipe, J. and Kumar, U. 2011. 'Unit Labor Costs in the Eurzone: The Competitiveness Debate Again', Levy Economics Institute of Bard College Working Paper No. 651.

Flassbeck, H. and Lapavitsas, C. 2013. 'The Systemic Crisis of the Euro-True Causes and Effective Therapies', Rosa Luxemburg Stiftung Studien

Foley, D. K. and Michl, T. R. 1999. Growth and Distribution, Cambridge, MA, Harvard University Press

Gabrisch, H. and Staehr, K. 2013. The Euro Plus Pact: competitiveness and cross-border capital flows in the EU countries, Mimeo

Galbraith, J. K. 1972. Power and the useful economist, American Economic Review, vol. 63, no. $1,1-11$

Garcimartin, C. and Rivas, L. 2012. The performance of the economies of Portugal and Spain throughout the crisis in the Euro Area: with or without you?, Mimeo, Universidad Rey Juan Carlos

Gaulier, G. and Vicard,V. 2012. The signature of Euro Area imbalances, Mimeo, Banque de France Ghosh, J. 2013. Interview, World Economic Association Newsletter, vol. 3, no. 3, 9-11

Goldstein, M. and Khan M. S. 1985. Income and price effects in foreign trade', pp.10411105 in Jones, R. W. and Kenen, P. B. (eds), Handbook of International Economics, Volume II, Amsterdam, Elsevier Science Publishers 
Gordon, R. J. and Krenn, R. 2010. 'The End of the Great Depression 1939-41: Policy Contributions and Fiscal Multipliers', NBER Working Paper 16380

Gros, D. 2011. 'Competitiveness Pact: Flawed Economics', CEPS Commentaries, Centre for European Policy Studies

Guajardo, J., Leigh, D. and Pescatori, A. 2011. 'Expansionary Austerity: New International Evidence', IMF Working Paper WP/11/158, http://www.imf.org/external/pubs/ft/wp/2011/ wp11158.pdf

Hein, E. and Tarassow, A. 2010. Distribution, aggregate demand and productivity growth-theory and empirical results for six OECD countries based on a post-Kaleckian model, Cambridge Fournal of Economics, vol. 34 no. 4, 727-54

Hein, E. and Vogel, L. 2008. Distribution and growth reconsidered: empirical results for six OECD countries, Cambridge fournal of Economics, vol. 32, no. 3, 479-511

Herndon, T., Ash, M. and Pollin, R. 2013. 'Does High Public Debt Consistently Stifle Economic Growth? A Critique of Reinhart and Rogoff', Working Paper Political Economy Research Institute, University of Massachusetts at Amherst.

Hervé, K. 2001. Estimations des élasticités du commerce extérieur sur l'ensemble des biens et services pour un panel de 17 pays, Économie et Prévision, vol. 147, no. 1, 19-36.

IMF. 2012. World Economic Outlook, Coping with High Debt and Sluggish Growth, Washington, DC, IMF

Judt, T. 2010. Ill Fares the Land:A Treatise on Our Present Discontents, London, Penguin Books

Keynes, J. M. 1919. The Economic Consequences of the Peace, New York: Harcourt, Brace and Howe

Keynes, J. M. 1936/1973. The General Theory of Employment, Interest and Money, London, Macmillan and Cambridge University Press

Kleinknecht, A., Naastepad, C. W. M., Storm, S. and Vergeer, R. 2013. Labour market rigidities can be useful, pp. 175-91 in Fadda, S. and Tridico, P. (eds.) Financial Crisis, Labour Markets and Institutions, London, Routledge

Koukouritakis, M. 2006. EU accession effects on export performance: the case of Greece, SouthEastern Europe fournal of Economics, vol. 2, 147-66

Lane, P. R. 2013. 'Capital Flows in the Euro Area', European Economy, Economic Papers 497, Directorate-General for Economic and Financial Affairs

Lane, P. R. and Pels, B. 2012. 'Current Account Imbalances in Europe', IIIS Discussion Paper No. 397, Trinity College Dublin

Lapavitsas, C. et al. 2011. 'Breaking Up? A Route Out of the Eurozone Crisis', RMF Occasional Report 3

Lee, S. and McCann, D. (eds.) 2011. Regulating for Decent Work: New Directions in Labour Market Regulation, London, Palgrave

Mitchell J., Solomou, S. and Weale, M. 2009. 'Monthly and Quarterly GDP Estimates for Interwar Britain', National Institute of Economic and Social Research Working Paper

Mazzucato, M. 2013. The Entrepreneurial State-Debunking Public vs. Private Sector Myths. London, Anthem Press

Onaran, Ö. and Galanis, G.. 2012. 'Is Aggregate Demand Wage-led or Profit-led: National and Global Effects', Conditions of Work and Employment Series No. 40, International Labour Organization

Palma, J. G. 2009. The revenge of the market on the rentiers. Why neo-liberal reports of the end of history turned out to be premature, Cambridge fournal of Economics, vol. 33, no. 4, 829-69

Pianta, M. and Lucchese, M. 2012. Industrial and innovation policies in the European Union, 139-148 in Garibaldo, F. Baglioni, M. Casey, C. and Telljohann, V. (eds.) Workers, Citizens, Governance: Socio-Cultural Innovation at Work, Berlin, Peter Lang

Robinson, J. 1946/47. The pure theory of international trade, Review of Economic Studies, vol. 14 , no. $2,98-112$

Senhadji, A. 1997. 'Time-series Estimation of Structural Import Demand Equations: A CrossCountry Analysis', IMF Working Paper WP/97/132

Senhadji, A. and Montenegro, C. 1998. 'Time-series Estimation of Export Demand Equations: A Cross-Country Analysis', IMF Working Paper WP/98/149

Schröder, E. 2011. Trade balances in Germany and the United States: Demand dominates price, term paper for Advanced Macroeconomics, New School for Social Research 


\section{Page 20 of 28 S. Storm and C. Naastepad}

Setterfield, M. (ed.) 2002. The Economics of Demand-Led Growth: Challenging the Supply-side Vision of the Long Run, Cheltenham, Edward Elgar

Sinn, H. W. 2012. Wir sitzen in der Falle, Frankfurter Allgemeine Zeitung, 18 February

Solow, R. M. 1998. What is labour-market flexibility? What is it good for?, Proceedings of theBritish Academy, vol. 97, 189-211

Soros, G. 2013. 'How to save the EU from the Euro crisis', http://www.theguardian.com/ business/2013/apr/09/george-soros-save-eu-from-euro-crisis-speech [date last accessed: 09 September 2014]

Souziakis, E. and Antunes, M. 2011. Growth performance in Portugal since the 1960s: a simultaneous equation approach with cumulative causation characteristics, Mimeo, University of Coimbra

Stockhammer, E., Onaran, Ö. and Ederer, S. 2009. Functional income distribution and aggregate demand in the Euro area, Cambridge fournal of Economics, vol. 33, no. 1, 139-59

Stockhammer, E. and Sotiropoulos, D. P. 2012. 'Rebalancing the Euro Area: The Costs of Internal Devaluation', Post Keynesian Economics Study Group Working Paper 1206

Storm, S. and Naastepad, C. W. M. 2007. OECD demand regimes (1960-2000), fournal of Post Keynesian Economics, vol. 29, no. 2, 211-46

Storm, S. and Naastepad, C. W. M. 2009. Labour market regulation and labour productivity growth: evidence for 20 OECD countries 1984-2004, Industrial Relations, vol. 48, no. 4, 629-54

Storm, S. and Naastepad, C. W. M. 2012. Macroeconomics beyond the NAIRU, Cambridge, MA, Harvard University Press

Varoufakis, Y., Holland, S. and Galbraith, J. K. 2013. 'Modest Proposal for Resolving the Eurozone Crisis - Version 4.0', http://yanisvaroufakis.eu/euro-crisis/modest-proposal/ [date last accessed: 09 September 2014]

Wyplosz, C. 2010. Germany, current accounts, and competitiveness, Voxeu.org; http://www. voxeu.org/index.php?q=node $/ 4820$

\section{Appendix}

We first present evidence that SE trade deficits are driven by the difference between domestic and foreign demand growth. We then outline our growth model.

\section{Imports}

We estimated the following import demand functions (linear in growth rates) for 1995-2008 (growth is denoted by a hat ${ }^{\wedge}$ ):

Table A.1. Estimated import demand equation, 1995-2008; annual data

\begin{tabular}{|c|c|c|c|c|c|}
\hline & 21 OECD Countries & Greece & Italy & Portugal & Spain \\
\hline Real GDP growth & $\begin{array}{l}2.10^{\star \star \star} \\
(14.40)\end{array}$ & $\begin{array}{l}2.29 \star \star \star \\
(3.60)\end{array}$ & $\begin{array}{l}2.75^{\star \star \star} \\
(6.92)\end{array}$ & $\begin{array}{l}2.22^{\star \star \star} \\
(6.06)\end{array}$ & $\begin{array}{l}2.53^{\star \star \star} \\
(6.75)\end{array}$ \\
\hline RULC growth & $\begin{array}{l}-0.24 \\
(-1.68)\end{array}$ & $\begin{array}{l}0.02 \\
(0.07)\end{array}$ & $\begin{array}{l}-0.24 \\
(-1.77)\end{array}$ & $\begin{array}{l}-0.16 \\
(-0.37)\end{array}$ & $\begin{array}{l}-0.10 \\
(-0.47)\end{array}$ \\
\hline & 0.95 & 0.49 & 0.77 & 0.78 & \\
\hline $\mathrm{F}$ & $103.8^{\star \star \star}$ & $8.4^{\star}$ & $24.1^{\star \star \star}$ & $18.6^{\star \star \star}$ & $101.5^{\star \star \star}$ \\
\hline DW & n.a. & 1.80 & 1.67 & 1.76 & 1.89 \\
\hline \# observations & 21 & 13 & 13 & 13 & 12 \\
\hline
\end{tabular}

Notes: The table reports the estimates of OLS Prais-Winsten AR(1) regressions for Greece, Italy and Portugal. The equation for Spain was estimated using Arima AR(1); log likelihood $=-23.89$. Robust $t$-values are reported in parentheses. ${ }^{\star \star \star},{ }^{\star \star},{ }^{\star}$ indicate statistical significance at the $1 \%, 5 \%$ and $10 \%$ levels, respectively. The $21 \mathrm{OECD}$ countries in the first regression include Australia, Austria, Belgium, Canada, Denmark, Germany, Ireland, Finland, Greece, France, Italy, Japan, the Netherlands, New Zealand, Norway, Portugal, Spain, Sweden, Switzerland, the UK and the USA. Annual data are from the AMECO database. 


$$
\hat{m}=\eta_{Y} \hat{y}+\eta_{C} \hat{c}
$$

where $m=$ real imports of country $j$ (at constant 2005 prices); $y=$ real GDP of country $j$ (at constant 2005 prices); and $c=$ relative unit labour cost (RULC) of country $j$ (performance is measured relative to the rest of 36 industrial countries: double export weights). $\eta_{Y}=$ the income elasticity of import demand; and $\eta_{C}=$ the RULC elasticity of import demand. Equation (T.1) was estimated using annual average growth rates for real imports, real GDP and RULC (Table A.1) and using seasonally adjusted quarterly growth rates (Table A.2). We also estimated the import function for a sample of 21 OECD countries (using average annual growth rates for the period 1995-2008) and obtained a long-run demand elasticity of imports of 2.1 (Table A.1, first column). Our estimates of $\eta_{Y}$ are of the same order of magnitude-close to 2-as the long-run income elasticities of import demand (based on aggregate data) found in the literature (see Table A.3). When we estimate import growth based on GDP growth,

Table A.2. Estimated import demand equation, 1996-2008; quarterly data

\begin{tabular}{lllll}
\hline & Greece & Italy & Portugal & Spain \\
\hline Real GDP growth & $0.85^{\star}$ & $2.58^{\star \star \star}$ & $1.54^{\star \star \star}$ & $2.56^{\star \star \star}$ \\
RULC growth & $(1.95)$ & $(7.18)$ & $(5.04)$ & $(10.4)$ \\
& 0.10 & 0.01 & -0.14 & 0.47 \\
R2 & $(0.94)$ & $(0.32)$ & $(-0.77)$ & $(1.55)$ \\
F & 0.19 & 0.44 & 0.35 & 0.68 \\
DW & $2.5^{\star}$ & $27.5^{\star \star \star}$ & $17.4^{\star \star \star}$ & $57.5^{\star \star \star}$ \\
\# observations & 1.87 & 2.07 & 1.86 & 1.76 \\
\hline
\end{tabular}

Notes: The table reports OLS Prais-Winsten AR(1) regressions. Robust $t$-values are reported in parentheses. ${ }^{\star \star \star},{ }^{\star \star},{ }^{\star}$ indicate statistical significance at the $1 \%, 5 \%$ and $10 \%$ levels, respectively. The quarterly data are from the Eurostat Database.

Table A.3. Estimates of income elasticities of import demand

\begin{tabular}{lcclccc}
\hline & Greece & Italy & Portugal & Spain & EU-12 & OECD \\
\hline Andersen (1993) & & 1.62 & & 1.89 & & \\
Senhadji (1997) & 1.32 & 1.75 & 1.42 & 1.70 & & \\
Bennett et al. (2008) & 1.48 & 1.97 & 1.55 & 2.28 & & \\
Bagnai (2010) & 3.17 & 1.29 & 1.42 & 1.91 & & 1.89 \\
Bussière et al. (2011) & & 2.71 & & & & \\
Garcimartin and Rivas (2012) & & 2.14 & & & 2.04 & 1.85 \\
$\begin{array}{l}\text { Onaran and Galanis (2012) } \\
\text { Chen } \text { et al. (2012) }\end{array}$ & 1.99 & 1.91 & 1.61 & 2.08 & 2.04 & 1.87 \\
Average & & & & & & \\
\hline
\end{tabular}

Sources: Andersen (1993), table 1, estimates for 1960-90; Senhadji (1997), estimates for 1960-93; Bennett et al. (2008), Table VII.1 (p. 77), estimates are for 1973-2006.; Bagnai (2010), Table 3, estimates are for 1960-2006; Bussière et al. (2011), Table 4, estimates for 18 OECD countries (1985Q1-2010Q2); Garcimartin and Rivas (2012), estimates based on data for 1975-2010; Onaran and Galanis (2012), Table 9A; Chen et al. (2012), Table 7, estimates are for 1990-2009. 


\section{Page 22 of 28 S. Storm and C. Naastepad}

Table A.4. Import structure by end-use (\%) (2001-8) and total import content of GDP components (2005)

\begin{tabular}{llccc}
\hline & Greece & Italy & Portugal & Spain \\
\hline End-use category of imports: & & & & \\
Intermediate goods & 50.2 & 55.0 & 56.8 & 57.5 \\
Capital goods & 15.0 & 9.6 & 10.3 & 11.1 \\
Household consumption goods & 22.8 & 16.9 & 20.0 & 18.4 \\
Mixed goods: & 11.9 & 12.8 & 11.0 & 12.4 \\
passenger cars & 5.6 & 7.8 & 5.8 & 7.3 \\
medicines & 4.2 & 2.3 & 2.6 & 2.5 \\
Other non-classified imports & 0.2 & 5.7 & 1.9 & 0.5 \\
Total import content of: & $24.1(14.1)$ & $21.3(8.1)$ & $29.0(14.4)$ & $24.0(11.8)$ \\
Private consumption & $9.9(0.3)$ & $7.20 .6)$ & $9.5(1.6)$ & $11.3(2.4)$ \\
Government consumption & $35.5(22.0)$ & $27.3(13.0)$ & $36.1(19.0)$ & $28.3(14.0)$ \\
Investment & 25.9 & 29 & 38.9 & 34.2 \\
Exports & & & &
\end{tabular}

Note: The direct import content is given within parentheses.

Source: Data on end-use category of imports are from the OECD STAN Database. Data on import content are from Bussière et al. (2011). The direct import content of exports is zero, because the re-exports of imports were excluded from their analysis.

the estimated imports closely track actual imports-leaving almost no variance to be explained by other factors. How can this be explained? First, most imported goods and services are complementary ('non-competing') imports-often energy, machines and intermediate inputs - for which no immediate substitutes are produced at home (Table A.4). Second, we should look not just at the direct import content of GDP but at the total import content, which is much larger, because GDP growth indirectly induces additional imports through backwards production linkages. The total import content is about twice as high as the direct import content (Bussière et al., 2011, see Table A.4). If we use the total import content percentages of Table A.4 and AMECO data on the growth of private and public consumption, investment and exports, we can account for the whole of import growth in Greece, Italy, Portugal and Spain during 1995-2008. The high direct and indirect import content of GDP growth shows up in our income elasticities taking values close to 2 .

Turning now to the RULCs elasticities of import demand: do our non-significant estimates of $\eta_{C}$ in Tables A.1 and A.2 mean that relative unit labour costs do not matter at all? We don't think so. As we can see, $\eta_{C}$ takes a value of -0.24 and is close to statistical significance at $10 \%$ for the group of 21 OECD countries and (separately) for Italy. This points to some labour cost sensitivity of imports, however limited. Unfortunately, most other studies are not directly comparable to ours, because these estimate the relative-price elasticity of import demand, $\eta_{P}$, rather than $\eta_{C}$. As has been argued in the main text, $\eta_{C}$ takes a value of onefifth or less of $\eta_{P}$, also depending on the degree of cost 'pass-through' (Goldstein and Khan, 1985). Athanasoglou and Bardaka (2010) find that $\eta_{C}$ takes a value of one-fourth of $\eta_{P}$ in the case of Greek manufacturing exports. We divided available country-specific estimates of $\eta_{P}$ by 2 so as to make them comparable with our estimates of $\eta_{C}$. These converted estimates (appearing in Table A.5) corroborate the conclusion that the sensitivity of imports to RULCs is limited. 


\section{Exports}

We estimated the following standard export demand function (in growth):

$$
\hat{e}=\varepsilon_{Y} \hat{y}_{W}-\varepsilon_{C} \hat{c}
$$

where $e=$ real exports of country $j$ (at constant 2005 prices); $y_{W}=$ real GDP of the OECD countries (at constant 2005 prices); and $c$ is defined above. $\varepsilon_{Y}=$ the world income elasticity of export demand; and $\varepsilon_{C}=$ the RULC elasticity of export demand. Equation (T.2) was estimated using annual average growth rates for exports, OECD GDP and RULC (Table A.6). Estimation results based on (seasonally adjusted) quarterly growth rates appear in Table A.7. $\varepsilon_{Y}$ (generally significant at $1 \%$ ) takes a value of 2 for the group of $21 \mathrm{OECD}$ countries and individually for Greece, Portugal and Spain. For Italy, $\varepsilon_{Y}$ is about 1.5. These findings are in line with the literature (Table A.8). Turning to $\varepsilon_{C}$, according to Table A.6 (annual data), $\varepsilon_{C}$ equals -0.44 for the OECD countries as a group, and it ranges between -0.35 for Italy and -0.56 for Portugal; $\varepsilon_{C}$ is not statistically significant for Greece. The estimates of $\varepsilon_{C}$ based on quarterly data (Table A.7) all turn out insignificant. Our estimates of $\varepsilon_{C}$ are similar to average values for $\varepsilon_{C}$ from earlier studies (Table A.9).

Table A.5. Estimates of RULC elasticities of import demand

\begin{tabular}{lllllll}
\hline & Greece & Italy & Portugal & Spain & EU-12 & OECD \\
\hline Andersen (1993) & & -0.11 & & -0.12 & & \\
Senhadji (1997) & -0.81 & -0.18 & -0.59 & -0.37 & & \\
$\begin{array}{l}\text { Bennett } \text { et al. (2008) } \\
\text { Athanasoglou (2011) }\end{array}$ & -0.39 & insignif. & -0.26 & -0.14 & & \\
Bussière et al. (2011) & -0.17 & & & & & -0.07 \\
$\begin{array}{l}\text { Garcimartin and Rivas (2012) } \\
\text { Onaran and Galanis (2012) }\end{array}$ & & -0.23 & -0.41 & -0.22 & & \\
$\begin{array}{l}\text { Chen } \text { et al. (2012) } \\
\text { Average }\end{array}$ & -0.46 & -0.13 & -0.42 & -0.21 & -0.16 & -0.07 \\
\hline
\end{tabular}

Sources: See sources of Table A.3. The relative price elasticities of Anderson (1993), Senhadji (1997), Bennett et al. (2008), Athanasoglou (2011), Bussière et al. (2011), Garcimartin and Rivas (2012) and Chen et al. (2012) have been converted into RULC elasticities (as explained in the text).

Table A.6. Estimated export demand equation, 1995-2008; annual data

\begin{tabular}{|c|c|c|c|c|c|}
\hline & 21 OECD countries & Greece & Italy & Portugal & Spain \\
\hline World GDP growth & $\begin{array}{l}1.82^{\star \star \star} \\
(16.72)\end{array}$ & $\begin{array}{l}2.58^{\star \star \star} \\
(4.54)\end{array}$ & $\begin{array}{l}1.35^{\star \star \star} \\
(4.47)\end{array}$ & $\begin{array}{l}1.85^{\star \star \star} \\
(9.18)\end{array}$ & $\begin{array}{l}2.28^{\star \star \star} \\
(5.34)\end{array}$ \\
\hline RULC growth & $\begin{array}{l}-0.44^{\star \star} \\
(-1.91)\end{array}$ & $\begin{array}{l}-0.45 \\
(-0.77)\end{array}$ & $\begin{array}{c}-0.35^{\star} \\
(-1.92)\end{array}$ & $\begin{array}{l}-0.56^{\star} \\
(-1.96)\end{array}$ & $\begin{array}{l}-0.46^{\star \star} \\
(-2.37)\end{array}$ \\
\hline$R^{2}$ & 0.93 & 0.60 & 0.680 .87 & 0.80 & \\
\hline $\mathrm{F}$ & $142.8^{\star \star \star}$ & $11.3^{\star \star} 10.9^{\star \star}$ & $42.1^{\star \star \star}$ & $18.1^{\star \star \star}$ & \\
\hline DW & n.a. & 2.08 & 1.99 & 1.95 & 1.60 \\
\hline \# observations & 21 & 13 & 13 & 13 & 13 \\
\hline
\end{tabular}

Notes: The estimates are based on OLS Prais-Winsten AR(1) regressions. See notes to Table A.1. 
Page 24 of 28 S. Storm and C. Naastepad

Table A.7. Estimated export demand equation, 1996-2008; quarterly data

\begin{tabular}{lllll}
\hline & Greece & Italy & Portugal & Spain \\
\hline World GDP growth & $2.29^{\star \star}$ & $1.66^{\star \star \star}$ & $2.05^{\star \star \star}$ & $2.44^{\star \star \star}$ \\
RULC growth & $(2.68)$ & $(3.89)$ & $(6.99)$ & $(8.74)$ \\
& -0.33 & 0.01 & -0.05 & 0.22 \\
R2 & $(-0.91)$ & $(0.38)$ & $(-0.24)$ & $(1.11)$ \\
F & 0.21 & 0.24 & 0.56 & $39.1^{\star \star \star}$ \\
\# observations & $3.7^{\star \star}$ & $7.8^{\star \star}$ & $27.6^{\star \star \star}$ & 1.91 \\
\hline
\end{tabular}

Notes: The table reports the estimates of OLS Prais-Winsten AR(1) regressions. Robust $t$-values are reported in parentheses. ${ }^{\star \star \star},{ }^{\star \star},{ }^{\star}$ indicate statistical significance at the $1 \%, 5 \%$ and $10 \%$ levels, respectively. The quarterly data are from the Eurostat Database.

Table A.8. Estimates of world income elasticities of export demand

\begin{tabular}{|c|c|c|c|c|c|}
\hline & Greece & Italy & Portugal & Spain & EU-12 \\
\hline Andersen (1993) & & 2.08 & & 2.94 & \\
\hline Senhadji and Montenegro (1998) & 2.81 & 2.26 & 1.30 & 2.86 & \\
\hline European Commission (2010) & & 1.08 & & 1.36 & 1.41 \\
\hline Bayoumi et al. (2011) & & & & & 1.80 \\
\hline Garcimartin and Rivas (2012) & & & 1.88 & 2.53 & \\
\hline Chen et al. (2012) & & & & & 1.26 \\
\hline Average & 2.81 & 1.81 & 1.59 & 2.42 & 1.49 \\
\hline
\end{tabular}

Sources: Andersen (1993), Table 1, estimates for 1960-90; Senhadji and Montenegro (1998), estimates for 1960-93; European Commission (2010), no years given; Bayoumi et al. (2011), estimates for 18 OECD countries (1980-2009); Garcimartin and Rivas (2012), estimates for 1975-2010; Chen et al. (2012), Table 7, estimates for 1990-2009.

Table A.9. Estimates of RULC elasticities of export demand

\begin{tabular}{lccccc}
\hline & Greece & Italy & Portugal & Spain & EU-12 \\
\hline Andersen (1993) & & -0.11 & & -0.27 & \\
Senhadji and Montenegro (1998) & -0.35 & -0.07 & -1.46 & -0.09 & \\
NiGEM (Herve, 2001) & -0.44 & -0.25 & -1.22 & -0.41 & \\
ECB (2005) & & -0.21 & & -0.29 & \\
ECB NMCM model & -0.60 & -0.61 & & -0.66 & \\
Koukouritakis (2006) & & & & -0.33 & \\
Bank of Spain (2007) & & -0.86 & -0.66 & & -0.23 \\
European Commission (2010) & & & 0.0 & & -0.28 \\
Souziakis and Antunes (2011) & -0.31 & & & & \\
Bayoumi et al. (2011) & & -0.12 & & -0.16 & \\
Bank of Grece (2012) & & -0.27 & -0.13 & -1.01 & \\
Storm and Naastepad (2012) & & & & \\
Garcimartin and Rivas (2012) & & -0.25 & -0.25 & -0.25 & -0.18 \\
Onaran and Galanis (2012) & -0.25 & -0.31 & -0.62 & -0.39 & -0.23 \\
Chen et al. (2012) & -0.39 & & & & \\
Average & & & & & \\
\hline
\end{tabular}

Note: Relative price elasticities have been converted into RULC elasticities (see text).

Sources: See sources for Table A.8. 
Trade imbalances and RULCs

Trade balance changes are driven overwhelmingly by domestic and world incomesnot by changes in relative unit labour cost. We define the trade balance, $b$, in growth rates as the difference between export and import growth. Using equations (T.2) and (T.1), we get:

$$
\hat{b}=\hat{e}-\hat{m}=\varepsilon_{Y} \hat{y}_{W}-\eta_{Y} \hat{y}-\left(\varepsilon_{C}+\eta_{C}\right) \hat{c}
$$

Equation (T.3) becomes Thirlwall's Law if we assume $\hat{b}=0$ and impose real exchange rate stability $\hat{c}=0$. The 'warranted rate of growth' then equals:

$$
\hat{y}^{\star}=\left[\varepsilon_{Y} / \eta_{Y}\right] \hat{y}_{W}
$$

Substituting equation (T.4) in equation (T.3) gives the following expression for $\hat{b}$ :

$$
\hat{b}=\eta_{Y}\left[\hat{y}^{\star}-\hat{y}\right]-\left(\varepsilon_{C}+\eta_{C}\right) \hat{c}=\text { constant }-\left(\varepsilon_{C}+\eta_{C}\right) \hat{c}
$$

If actual GDP growth is close to its long-run 'warranted' rate of growth, that is, $\hat{y}^{\star}-\hat{y} \approx 0$, then the constant term on the right-hand side is 0 , and $\hat{b}$ is a function of only RULC growth. If actual growth exceeds warranted growth, then the constant term will be negative (and vice versa). We estimated equation (T.5). Findings appear in Table A.10. For Greece, Italy and Portugal, the constant term is not statistically significant, meaning that actual GDP growth was close to the warranted rate. For Spain, the constant term is significant and negative, indicating that actual Spanish GDP growth exceeded its warranted growth rate, and this imbalance was showing up in a growing trade deficit. Spain cannot grow faster than the rest of the world without encountering external problems.

Table A.10. Trade balance equation, 1996-2007; quarterly data

\begin{tabular}{lllll}
\hline & Greece & Italy & Portugal & Spain \\
\hline Constant & -0.20 & -0.24 & -0.02 & $-0.60^{\star \star \star}$ \\
RULC growth & $(0.25)$ & $(0.83)$ & $(0.06)$ & $(2.99)$ \\
$(-0.41)$ & $(2.44)$ & $-0.31^{\star \star}$ & $0.34^{\star \star}$ & $-0.39^{\star \star}$ \\
Dummy1 & $5.51^{\star \star \star}$ & $(2.07)$ & $(2.16)$ & $-2.47^{\star \star}$ \\
& $(4.08)$ & $4.97^{\star \star \star}$ & $-3.47^{\star \star \star \star}$ & $(4.30)$ \\
Dummy2 & $-7.81^{\star \star \star}$ & $(7.37)$ & $(4.12)$ & \\
& $(3.18)$ & $\left(5.57^{\star \star \star}\right.$ & & 0.13 \\
R2 & 0.26 & 0.18 & & $10.0^{\star \star \star}$ \\
DW & $98.8^{\star \star \star}$ & $103.7^{\star \star \star}$ & 9.09 & 1.78 \\
\# observations & 1.91 & 2.00 & $9.7^{\star \star \star}$ & 47 \\
\hline
\end{tabular}

Notes: The table reports the estimates of OLS Prais-Winsten $\operatorname{AR}(1)$ regressions. Robust $t$-values are reported in parentheses. ${ }^{\star \star \star}, \star \star, \star \star$ indicate statistical significance at the $1 \%, 5 \%$ and $10 \%$ levels, respectively. The quarterly data are from Eurostat. Dummy1 for Greece (2003Q2 and 2004Q1); Italy (1996Q2); Portugal (2001Q1); and Spain (2003Q3 and 2004Q2). Dummy2 for Greece (2006Q4) and Italy (1997Q2 and 1998Q1). 


\section{Page 26 of 28 S. Storm and C. Naastepad}

Turning to the impact of RULC growth on the trade balance, we find no statistically significant coefficient for Greece, which confirms our (insignificant) results for $\left(\varepsilon_{C}+\right.$ $\eta_{C}$ ) in Tables A.1, A.2, A.6 and A.7. For Portugal, we find a positive impact of RULC growth on trade-balance growth. Our estimates of $\left(\varepsilon_{C}+\eta_{C}\right)$ are -0.31 for Italy and -0.39 for Spain; they match our earlier estimates in Tables A.1, A.2, A.6 and A.7. But whilst RULC growth did lead to a deterioration of the trade balance in both Italy and Spain, RULC increases over 1996-2008 do explain only $0.7 \%$ of the trade balance decline of Spain and $7.9 \%$ of that of Italy.

\section{The model}

We use a modified version of the model outlined in Storm and Naastepad (2012). Aggregate output, $x$ is determined by effective demand:

$$
x=c+g+i+e-m
$$

where $c$ is private consumption, $g$ is public current expenditure, $i$ is investment, $e$ is exports and $m$ is imports; all variables are in constant prices. Income distribution (over wages and profits) is the key driver of the model, and hence we define the real wage share or ULC as:

$$
v=(W / P) \lambda^{-1}=w \lambda^{-1}
$$

$W$ is the nominal wage (per hour of work) and $P$ is the aggregate price level. Importantly, the real wage share is equal to real labour cost per unit of output. We assume that the real wage $w=(W / P)$ is fixed at any point in time, from institutions and a history of bargaining. In growth rates, equation (A.2) becomes:

$$
\hat{v}=\hat{w}-\hat{\lambda}
$$

From equation (A.2), and at a given level of labour productivity $\lambda$, it follows that there exists a negative relationship between the real wage rate and the profit share. To see this, note that by definition, the (real) profit share $\pi$ is equal to 1 minus the wage share:

$$
\pi=1-\frac{W \lambda^{-1}}{P}=1-v
$$

Expressed in growth this gives:

$$
\hat{\pi}=\frac{\Delta \pi}{\pi}=-\frac{v}{\Delta} \frac{\Delta v}{v}=-\theta(\hat{w}-\hat{\lambda})
$$

where $\theta=(v / \pi)=v /(1-v)>0$. Profit share growth declines if real wage growth exceeds labour productivity growth.

Consumption demand is a function of wage income and capital income; denoting the saving propensity by $\sigma$ and using the subscripts $w$ and $\pi$ to refer to wages and profits, respectively, wage earners consume $\left(1-\sigma_{W}\right)$ of their income, whilst capitalists' average 
consumption propensity equals $\left(1-\sigma_{\pi}\right)$. We assume that $\left(\sigma_{W}<\sigma_{\pi}\right)$. Accordingly, we assume:

$$
c=\left(1-\sigma_{w}\right) w \lambda^{-1} x+\left(1-\sigma_{\lambda}\right) \pi x-t=\left[\left(1-\sigma_{w}\right) v+\left(1-\sigma_{\lambda}\right)(1-v)\right] x-t
$$

where $t$ is aggregate direct tax payments.

Substituting equations (A.3) and (A.6) into (A.1) and rearranging, we get:

$$
x=\frac{(g-t)+i+e-m}{\left[1-\left(1-\sigma_{z}\right) v-\left(1-\sigma_{\pi}\right)(1-v)\right]}=\mu^{-1}\left(g^{*}+i+e-m\right)
$$

We define $g^{\star}=g-t$ as government current expenditure minus direct tax payments (the government's current account deficit). Note that $\mu^{-1}=1 /\left[1-\left(1-\sigma_{w}\right) v-\left(1-\sigma_{\lambda}\right)(1-v)+\zeta\right]$ is the Keynesian multiplier $\left(\mu^{-1}>1\right)$, the magnitude of which depends, through $v$ on the distribution of income, the real wage and productivity. Totally differentiating equation (A.7), dividing through by $x$ and rearranging give us this expression for demand-led output growth:

$$
\hat{x}=-\hat{\mu}+\frac{\mu^{-1} g^{*}}{x} \hat{g}^{*}+\frac{\mu^{-1} i}{x} \hat{i}+\frac{\mu^{-1} e}{x} \hat{e}=-\hat{\mu}+\psi_{g} \hat{g}^{*}+\psi_{i} \hat{i}+\psi_{e} \hat{e}-\psi_{m} \hat{m}
$$

where $\psi_{g}, \psi_{i}, \psi_{e}$ and $\psi_{m}$ are the (multiplier-adjusted) shares in GDP of net government current expenditure, investment, exports and imports, respectively. Since $\mu=\left[\sigma_{\lambda}-v\left(\sigma_{\lambda}-\sigma_{w}\right)+\zeta\right]$, we derive its growth rate as a function of ULC growth as follows:

$$
\hat{\mu}=-\frac{v}{\lambda}\left(\sigma_{\pi}-\sigma_{w}\right) \hat{v}=-\zeta\left(\sigma_{\pi}-\sigma_{w}\right)(\hat{w}-\hat{\lambda})
$$

where $\xi$ is the positive fraction $(v / \mu)$. We assume the following relationships for investment (in A.10), exports (in A.11) and imports (in A.12):

$$
\begin{gathered}
\hat{i}=\varphi_{0} \hat{b}+\varphi_{1} \hat{\pi}+\varphi_{2} \hat{x}-\varphi_{3} r_{k} \\
\varphi_{0}, \varphi_{1}, \varphi_{2}, \varphi_{3}>0 \\
\hat{e}=\varepsilon_{Y} \hat{y}-\varepsilon_{C} \hat{v} \\
\hat{m}=\eta_{Y} \hat{x}+\eta_{C} \hat{v}
\end{gathered}
$$

$\hat{b}$ represents other, autonomous factors (mainly 'animal spirits' of entrepreneurs) influencing investment decisions. $\varphi_{1}$ is the elasticity of investment with respect to the profit share. $\varphi_{2}$ is the accelerator effect and $\varphi_{3}$ is the elasticity of investment with 


\section{Page 28 of 28 S. Storm and C. Naastepad}

respect to the real interest rate $r_{k}$. In equation (A.11), $\varepsilon_{Y}$ is the elasticity of exports with respect to world GDP, $\hat{y}$, and $\varepsilon_{C}$ is the elasticity of exports with respect to change in RULCs (for simplicity and without loss of generality, we normalise labour costs of the rest of world to 1 ). In equation (A.12), $\eta_{Y}$ is the elasticity of imports with respect to domestic GDP and $\eta_{C}$ is the elasticity of imports with respect to RULCs. Substitution of equations (A.9), (A.10), (A.11), and (A.12) into (A.8) gives output growth as:

$$
\hat{x}=\frac{\psi_{i} \psi_{0} \hat{b}+\psi_{g} \hat{g}^{*}+\psi_{e} \eta_{Y} \hat{y}-\psi_{i} \varphi_{3} r_{k}}{1-\psi_{i} \varphi_{2}+\psi_{m} \eta_{Y}}+\frac{\left[\xi\left(\sigma_{\pi}-\sigma_{w}\right)-\psi_{i} \varphi_{1} \theta-\psi_{e} \sum_{C}-\psi_{m} \eta_{C}\right]}{1-\psi_{i} \varphi_{2}+\psi_{m} \eta_{Y}}[\hat{w}-\hat{\lambda}]
$$

Note that for equation (A.13) to be economically meaningful, we must assume that $\left[1-\psi_{i} \varphi_{2}+\psi_{m} \eta_{C}\right]>0$. $\Theta$ represents all autonomous influences on output growth:

$$
\Theta=\frac{\psi_{i} \psi_{0} \hat{b}+\psi_{g} \hat{g}^{\star}+\psi_{e} \eta_{Y} \hat{y}-\psi_{i} \psi_{3} r_{k}}{1-\psi_{i} \psi_{2}+\psi_{m} \eta_{Y}}
$$

Let us further define:

$$
\begin{gathered}
C_{D}=\frac{\left[\xi\left(\sigma_{\pi}-\sigma_{\mathrm{w}}\right)-\psi_{i} \varphi_{1} \theta\right]}{1-\psi_{i} \phi_{2}+\psi_{m} \eta_{Y}} \\
C_{T}=-\frac{\left[\psi_{e} \varepsilon_{C}+\psi_{m} \eta_{C}\right]}{1-\psi_{i} \phi_{2}+\psi_{m} \eta_{Y}}
\end{gathered}
$$

$C_{D}$ stands for the 'domestic' impacts of ULC growth on output growth. $C_{T}$ captures the impacts of ULC growth on demand growth operating through exports and imports. The total impact of ULC growth on output growth equals $C=C_{D}+C_{T}$. Output growth can thus be expressed as:

$$
\hat{x}=\Theta+C_{D}[\hat{w}-\hat{\lambda}]-C_{T}[\hat{w}-\hat{\lambda}]=\Theta+C \hat{v}
$$

where $\hat{v}=\hat{w}-\hat{\lambda}$ represents ULC growth (from equation A.3). If $C>0$, growth is called wage-led. Alternatively, growth is profit-led if $C<0$. Equation (A.17) has been used in the estimations of Table 4. Finally, using equation (A.13) and differentiating output growth with respect to world income growth, we get the following impact effect $\eta_{Y}^{M}$ :

$$
\frac{\partial \hat{x}}{\partial \hat{y}}=\frac{\psi_{e}}{1-\psi_{i} \varphi_{2}+\psi_{m} \eta_{Y}} \times \eta_{Y}=\eta_{Y}^{M}>0
$$

$\eta_{Y}^{M}$ is the foreign income multiplier. Estimates of $\eta_{Y}^{M}$ appear in Table 4. 